\title{
Are the Kalasha really of Greek origin? The Legend of Alexander the Great and the Pre-Islamic World of the Hindu Kush ${ }^{1}$
}

\author{
Augusto S. Cacopardo \\ Università di Firenze
}

\begin{abstract}
The paper refutes the claim that the Kalasha may be the descendants of the Greeks of Asia. First, traditions of Alexandrian descent in the Hindu Kush are examined on the basis of written sources and it is shown that such legends are not part of Kalasha traditional knowledge. Secondly, it is argued that the Kalasha were an integral part of the pre-Islamic cultural fabric of the Hindu Kush, and cannot be seen as intruders in the area, as legends of a Greek descent would want them. Finally, through comparative suggestions, it is proposed that possible similarities between the Kalasha and pre-Christian
\end{abstract}

\footnotetext{
${ }^{1}$ Paper presented as a key-note address at the First International Conference on Language Documentation and Tradition, with a Special Interest in the Kalasha of the Hindu Kush Valleys, Himalayas - Thessaloniki, Greece, 7-9 November 2008. Scarcity of funds caused the scientific committee to decide to select for the forthcoming proceedings only linguistic papers. This is rather unfortunate because the inclusion in the volume of anthropological papers as well would have offered a good opportunity for comparing different views on the question of the Greek ascendancy of the Kalasha.
} 
Europe are to be explained by the common Indo-European heritage rather than by more recent migrations and contacts.

Keywords: Alexander the Great, Dionysus, Greeks, Hindu Kush, Indo-European, Kafirs, Kalasha.

The idea that the impenetrable mountain fastness of the Hindu Kush could conceal some stray descendants of the Greek colonists installed by Alexander the Great in Central Asia, has deeply fascinated British writers from the early times of the colonization of the Indian subcontinent. A Greek ancestry was claimed in those times by the rulers of several princely states of the mountains, by the Pashtun Afridi tribes (Caroe 1958: 44) and, purportedly, by the people of Nuristan (the former Kafirs of the Hindu Kush). In more recent years the same claim has been attributed to the Kalasha of Chitral. It is one of the aims of this contribution to investigate the origins of these narratives through an analysis of the written sources available and of the oral traditions of the people involved, taking into account also ethnographic and linguistic data (for genetic data see fn. 25). Another aim is to consider these narratives in the general frame of our knowledge of the pre-Islamic cultures of the Hindu Kush, in the light of most recent research. Finally, some cultural comparisons will be proposed.

\section{The 'Greek' Princes}

The earliest notice of a claim to Greek ancestry in the mountains known to the ancient Greeks as Paropamisos, was brought to Europe already in the 13th century by Marco Polo, the Venetian traveller, who reported in his famous book that the royal dynasty of Badakhshan descended directly from Alexander's marriage with the daughter of Darius, and for that reason all the kings of that line called themselves Zulkarnein, in memory of their great ancestor (Polo 2005: 37). Polo's report was confirmed over two centuries later by the emperor Babur ([1921] 1990: 22) - the founder of the Moghul imperial dynasty of India - who writes in his Memories ${ }^{2}$ that those rulers are said to

${ }^{2}$ The Babur Nama covers the period between 1493-94 and 1529. 
descend from Iskander Filkus. A further notice stating that Sultan Badakhshi was of the race of Sikandar Zulkarnain, Filikus Rumi ${ }^{3}$ comes from Mirza Haidar Dughlat (1895: 107), the author of Tarikh-iRashidi, who was a relative and contemporary of Babur. As for British authors they do not fail to mention this connection from the very beginning: we find it in Burnes (1833, [1842] 2003: 203), in Raverty ([1888] 1976: 156, 162), and in Leitner ([1894] 1985: app. IV).

Yet, the rulers of Badakhshan were not the only ones to claim descent from Alexander. We learn from Elphinstone (1815: 628) that the ruler of Darwaz also claimed Greek ancestry, and from Wood (1872: 155), who travelled to the sources of the river Oxus in 1838, that so did the ruler of Talikhan, a city on the borders of Badakhshan. Burnes (1833) adds to the list the princes of Shignan and Wakhan, and Raverty ([1888]: 162) the prince of Roshan; while Tanner (1891), finally, reports that all the princes of the upper Oxus states made the same claim (cf. Yule 1921: 160). Since these neighbouring rulers of the northern slopes of the Hindu Kush, however, were most probably all connected by ties of marriage or kinship - and even when this was not so, imitation would certainly have played a role - we can quite safely suppose that the origin of their claims is one and the same, i.e. the established tradition of an Alexandrian ancestry of the royal dynasty of Badakhshan. ${ }^{4}$

Claims to a Greek ancestry were not confined, however, to the Badakhshan and Oxus area. Reports about other claims to an Alexandrian origin come also from the southern slopes of the chain, i.e. the Northern Areas of Pakistan, from as far east as Hunza, Nager and Skardu in Baltistan. ${ }^{5}$ In the case of Nager, Schomberg (1935: 106) reports that the Mir was very proud of his descent from Alexander the Great and appreciated comments by his guests about his classic Greek profile; since, however, there is no trace of such ancestry in the oral traditions reported by Frembgen (1992), it could be that the claim was staged in British times by the rulers who took to their side, to exhibit some affinity with the new European lords. In the case of Skardu,

\footnotetext{
${ }^{3}$ Ney Elias, the English translator of Tarikh-i-Rashidi, explains in a footnote (Ib.) that Filikus appears to be the usual Oriental corruption of Philip Alexander's father.

${ }^{4}$ This dynasty was dethroned and replaced at the end of the 16th century by an Uzbek dynasty whose rulers bore the title of Mir, instead of Shah, like their ousted predecessors.

${ }^{5}$ And even from the western provinces of China (Burnes 1833).
} 
John Biddulph ([1880] 1986: 146-147), the first official British agent sent to the area (Keay [1979] 1990: 90), does not relate tales of Greek ancestry on the part of the ruling dynasty, but reports that the town itself was said to have been built by Alexander who named it Iskanderia, from which it was converted to its present form (Ib.). If we consider that Skardu is pronounced Iskardu by locals, it seems likely that the connection to Alexander (Iskander) is a construction inspired by the name itself of the city. In fact Vigne (1842 in Afridi 1988: 31) reports that the ruler Ahmad Shah was aware of the tradition, but said there was no reason for it within his knowledge.

As for Hunza, Lorimer (1935, II: 236), in a footnote, reports a folk tradition of descent of three tribes from people left by Alexander the Great, when he was on his way down from China, and Sidky (1999) relates what seems to be a fuller version of that tradition. ${ }^{6}$

A connection to Alexander also appears in the Tarikh-i-Hunza, an early 19th century work by Muhammad Riza Beg, where a Shah Rais ruler of Hunza, Nager and Gilgit is associated with Alexander the Great and is said to have been nominated as a governor of Gilgit by him (Holzwarth 2006: 175). Shah Rais - who is here completely estranged from his context - is in fact a historical figure: he was the offspring of a shah who ruled Chitral in the first half of the 17th century and claimed to descend from Alexander the Great, just as the shahs of Badakhshan did (Ib.). His father Shah Babur was indeed an offspring of that very royal lineage, who was forced into exile at the end of the 16th century when his reign was annexed by the Uzbek kingdom of Bukhara, and became the ruler of "Chetrar and Bashqar" (Raverty [1888] 1976: 162; Holzwarth 1994; Cacopardo \& Cacopardo 2001: 49). We are led again, here, to the established claim of the royal dynasty of Badakhshan.

A further notice of Alexandrian ancestry - related by Cunningham (1854: 39) as second-hand information - concerns the last ruling dynasty of Chitral, the Kator royal lineage. This notice is rather atypical because the dynasty of the last rulers of Chitral claims a very different ancestry, reaching back to the Timurid rulers of Herat in one version (Murtaza [1962] 1982: 71-72), and to the Persian king of Khorasan in another (Müller-Stellrecht 1980: 211). The tradition

\footnotetext{
${ }^{6}$ Of which, he informs us, a published version already existed in the Tarikhi Ahdi Atiqi Hunza by Qudratullah Beg (a work published in 1980 cf. Holzwarth 2006: 190).
} 
related by Cunningham, of which he does not mention the source, is probably to be connected, instead, to the Shah Babur mentioned above, who was in all likelihood the first independent Muslim ruler of Chitral and whose rule is documented in the year 1620 A.D. (Holzwarth 1996, 1999: 137-142; Cacopardo \& Cacopardo 2001: 4849). Shah Babur's claim to an Alexandrian ancestry was probably transferred in this case to the last rulers of Chitral, who belong in fact to a wholly separate dynasty. Once again, it appears, we are brought back to the same master-tradition.

From the sources listed above it seems therefore that the centre of the diffusion of the tradition in the northern reaches of the Hindu Kush is to be identified with the kingdom of Badakhshan, and in particular with its dethroned royal lineage.

There was however another corner of the Hindu Kush where the claim to a Greek ancestry must have been wholly independent from the Badakhshan tradition. The earliest reference to it is to be found in the Ayin Akbarì, a work by Abu-Fazl the main historian at the court of the Moghul emperor Akbar (1542-1605 A.D.), the grandson of Babur. The reference was noticed by some of the very early British authors who quote it in their writings, already in the 18th century. We are here at the southern borders of the chain, in the valleys of Swat and Bajaur, which were formerly governed by a dynasty of princes styled Sultani, who derived their lineage from a daughter of Alexander the Great (Rennell 1792: 162); first defeated by Babur in 1519 (Babur [1921] 1990: 368-370; Masson 1842: 217), they were subsequently dispossessed by the Yusufzai Pathans when they migrated there from Kabul (Raverty [1888] 1976: 204). The Sair-al bilad - an eyewitness account based on surveys made by one Mogul Beg between 1789 and 1790 for Captain Wilford - relates that in a village at the head of the Babaqara valley in Bajaur, nearby the ruins of the mighty fortress of Sultan Haidar Alì destroyed by Babur, there was still “...a small village called Kanbat, in which a few hundred families of the former race - the Arab - dwell, who are styled Iskandari”' (in Raverty [1888] 1976: 117).

Summing up, we may say that we have detected two surely independent centres of the tradition of Alexandrian descent in the Hindu Kush. One, Badakhshan, apparently very prolific, influencing a vast area on both sides of the main northern ridge. The other one seemingly more isolated in the southern ramparts of the chain and 
almost extinct, but originally extending from Bajaur to Swat. The Afridi tradition mentioned by Caroe (see above) could be connected to this centre.

What should we make of these traditions? The fact that they are well documented and centuries old may induce in the layman a belief in their historical quality. But for the historian and anthropologist this is hardly possible. In the absence, as is the case, of the support of any "local written record, Indian or Achaemenian, inscriptional or other of Alexander's passage through the country" (Caroe 1958: 45), an oral tradition just cannot reach back that far.

Jan Vansina - a historian and anthropologist who did pioneering work in the field of oral traditions - reports that he knows of no instance of a continuous series of witnesses going back more than three centuries (Vansina [1961] 1976: 311-312). We have found that among the Kalasha that limit can be exceeded, and in the case of the Kati of Nuristan there is proof of an oral tradition reaching back possibly even more than five centuries (Morgenstierne 1973b: 312). But this is absolutely exceptional, and we are here at the extreme limits of the span of time oral memory can cover. There is no way, therefore, that the traditions we are dealing with could go back to the times of Alexander. If they lasted for over six centuries, as Marco Polo's report testifies, this can only be explained by the fact that they must be nourished by some written source. For Olaf Caroe these traditions:

almost certainly have their origin in the body of western classical learning translated into Arabic in the days of the Abbasids of Baghdad, and are part of the Yunani or Greek lore which so largely influenced Islamic literae humaniores. It was thus that the great deeds of Sikandar Zul-qarnain - Alexander of the Two Horns - became a part of the folk-lore of the Muslim world. (Caroe 1958: 45; cf. Grossato 2008: 276)

If those classics had not been translated - he adds - the memory of Alexander's great feat would have been completely forgotten in India and Eastern Iran. The circumstance related by Polo that the rulers of Badakhshan all exhibited the title Zul-qarnain, an Arabic epithet used for Alexander in the Quran, brings strong support to Caroe's observation. We can quite safely conclude therefore that all these traditions, whether connected (as they mostly seem to be) or not, to 
the two main centres, were developed after the arrival of Islam in the area, and cannot be the fruit of an uninterrupted transmission from the times of Alexander or of his Greek successors in the area.

\section{The Greek 'Savages'}

Let us consider now the sources concerning the former Kafirs ${ }^{7}$ of the Hindu Kush, the speakers of Nuristani (formerly 'Kafiri') languages (Fussman 1972; Morgenstierne 1974; Edelman 1983; Strand 2001). Western neighbours of the Kalasha in present-day Afghan Nuristan, they were an independent constellation of tribes that remained unconquered by any State power, and polytheistic, until the end of the 19th century, when they were subdued and forcibly converted to Islam by the Amir of Afghanistan Abdur Rahman Khan ${ }^{8}$ (Kakar 1971; Cacopardo \& Cacopardo 2001: 182-185). The idea that they may be somehow connected to Alexander's colonists circulated in Europe already in the 19th century (Yule 1882: 821; Capus 1889: 18) and was reinforced by their fairer complexion as compared to the people of the plains, their customs of producing wine and using chairs and by other peculiar traits of their non-Islamic culture which seemed vaguely reminiscent of ancient Europe.

It was soon shown, however, that the idea was the fruit of a mistake committed by the very first author who provided an extensive account of the Kafirs, the Honourable Monstuart Elphinstone who was sent as the first British envoy to the King of Kabul in 1809. Elphinstone had read Rennell's work and had in mind the passage quoted above where he related the notice given in Abu Fazl's Ayin Akbari about a certain tribe in Bajaur who claimed descent from Alexander the Great. We have just seen that these are the former inhabitants of the region whose king, in the times of Babur, was Sultan Haidar Ali, and who had subsequently been displaced by the Yusufzai Pathans. However, when Elphinstone heard news of the Kafirs - who lived in the mountains just north of Bajaur - and their supposedly European traits he immediately thought that they may

\footnotetext{
${ }^{7}$ Kafirs, Arabic for infidel, is the term they were collectively referred to by their Muslim neighbours before their conversion.

${ }^{8}$ The Kalasha escaped the crusade because they were left on the British side of the border by the Durand Agreement of 1893 (Alder 1963: 287-299, 330-333).
} 
have been the people referred to in Abu Fazl's work (Elphinstone 1815: 617), and he resolved to send an envoy to their country to shed light on their customs and origins. The passage where this is related opens Elphinstone's chapter on the Kafirs and, though a few pages later their Greek ancestry is bluntly dismissed on linguistic grounds (Ib: 620), it probably left a durable impression on readers. Indeed, Elphinstone's book must have had a remarkable impact in England for it was the first detailed eye-witness account of the then totally unknown Kingdom of Kabul; it apparently generated a widespread belief in a possible Greek origin of the Kafirs that lasted throughout the 19th century (Mohan Lal 1834; Vigne 1840: 236; The Times 12.21.1895 in Jones 1966: 56; cf. Yule 1882: 821), in spite of the fact that his mistake was detected and explained by Yule already in 1882 (Ib; Capus 1889: 18), and that there was also no lack of dissenting opinions (Burnes 1833; Biddulph [1880] 1986: 132; Rousselet 1885: 219; The Times 02.11.1896 in Jones 1966: 58), including, as we have just seen, that of Elphinstone himself. In one account it is even conjectured that they must be the descendants of Greeks that conquered India long before Alexander, the Nysaens of the Dionysian myth (Holdich 1896).

As for the Kafirs themselves, it seems that they felt an affinity with the Europeans because it is reported that they prided themselves of being brothers of the Firingi ${ }^{9}$ (Wood [1841] 1872: 187); and we know of one instance in which a delegation of Kafirs appeared in a British military camp near Jalalabad in 1839, claiming ties of kinship with the Europeans (and was not well received by the officers in charge who did not see themselves as having possibly something in common with that wild-looking bunch) (Raverty 1859: 345-346). This feeling was probably generated by the common traits of a fairer complexion, of drinking wine, ${ }^{10}$ and of not being Muslims; but it is likely that it was also, to some extent, induced by their Islamic neighbours who were the first to find them similar to the Europeans "in their intelligence, habits and appearance as well as in their hilarious tone and familiarity, over their wine" (Burnes 1838: 329).

\footnotetext{
${ }^{9}$ Firingì, or Farangì, is a term used in the Muslim world probably since the Crusades to designate Europeans; it derives from Farans, France.

${ }^{10}$ Burnes (1833: 326) was assured by one of his Kafir informants that his tribe looked upon all as brothers, who wore ringlets and drank wine. If the British did not wear ringlets, they did show appreciation for wine.
} 
Wood ([1841] 1872: 186-187) wonders if the Kafirs' claim of brotherhood to Europeans was founded on tradition, or was a mere assumption of their own. The latter was most probably the case.

The oral traditions of the Nuristani in fact make no mention of the Greeks or of Alexander. We do not hear tales of descent from the great Macedonian conqueror, like the ones reported from Badakhshan. We have found only one instance in the literature in which the Kafirs explicitly state that their ancestors have come with Alexander the Great. From the secret British documents collected by Schuyler Jones, we learn that a delegation from Kafiristan applied to Ghulam Haidar the general who led the crusade of 1891-92 which caused the conversion of the region (then renamed Nuristan) - on May 23rd 1891 seeking protection from an impending raid against them on the part of a large Pathan tribal force. The document relates that the Kafirs stated that their tribe is of European descent, their ancestors having been brought from Europe into Kafiristan by Alexander the Great (Jones 1969: 41). The Amir Abdur Rahman was then trying to lure the Kafirs into submission without the use of military force and he granted the protection required by inducing the Pathan leaders to give up their planned attack. At that time, the Kafirs of the Bashgal valley had already known Colonel Robertson, who had spent a year among them in 1889-90, ${ }^{11}$ and the Lockhart mission before him (Lockhart \& Woodthorpe 1889). Also, they had surely been aware of the presence of the new European power in the area since the times of Elphinstone, and it is very likely that they had got wind of European conjectures about their origin; while Alexander the Great, on the other hand, must have been known to them also through the Islamic folk-lore of the people surrounding them (Müller-Stellrecht 1980: 201-206). We should not be far from the truth, therefore, if we suppose that in this isolated case the Kafirs resorted to the Alexandrian legend because they thought it could have been expedient, in that perilous

\footnotetext{
${ }^{11}$ Robertson's precious book (1896), an eye-witness account of Kafir society before its forced Islamization, has become a standard reference for the area. The only other extended first hand account of that world is in a manuscript collected by Morgenstierne in 1929 and published only recently (Cacopardo \& Schmidt 2006).
} 
circumstance, to present themselves as related to the powerful lords of the Indian empire. ${ }^{12}$

Apart from this single instance, whenever the question of origins is raised, the early sources (Burnes 1838: 326, [1842] 2003: 207; Vigne 1840: 236; Biddulph [1880] 1986: 132; Bellew 1891: 143; Robertson ([1896] 1974: 158) invariably report that the Kafirs believed themselves to be of Arab descent and to belong to the Quraish tribe; a no doubt fictitious pedigree that has however a very interesting meaning that we have investigated elsewhere. ${ }^{13}$

It is also quite certain that a connection of the Kafirs to the great Macedonian was not part of the early Asian Islamic tradition. This is proved indeed by the fact that Timur Laing, who made a fleeting incursion in their territory in 1398, could boast to have submitted a people who had never been conquered by any prince in the world, not even by Alexander the Great (Masson 1842: 200) ${ }^{14}$.

The idea that the Kafirs of the Hindu Kush could be connected to the Greeks of Asia, never seriously entertained by scholars, was in the end altogether set aside when their languages came under the scrutiny of professional linguists in the early decades of the 20th century. Georg Morgenstierne's work made clear that the Nuristani languages have no connection with Greek, apart from the distant common Indo-European roots. Since then linguists agree that they are an early off-shoot of the Indo-Iranian family, closer to the Indian than to the Iranian branch (Fussman 1972: 12-13; Morgenstierne 1974; Edelman 1983; Strand 1998, 2001).

\footnotetext{
${ }^{12}$ Another episode in which the Kafirs exhibit good knowledge of the international politics of the time and show their aptness at using pedigrees for political ends is reported by Robertson ([1896] 1974: 160).

${ }^{13}$ This legendary theme is a well established tradition throughout the Hindu Kush/Karakorum. We ourselves have recorded it many times in Southern Chitral (Cacopardo \& Cacopardo 2001: 85, 111, 213-215, 244, 246, 268, 271-272). The true meaning of the legend is in fact a statement of ancient Kafir ancestry because the supposed connection is through Abu Jahel, a member of the Quraish tribe who was an arch-enemy of Islam (Cacopardo \& Cacopardo 2001: 213-214).

${ }^{14}$ That Alexander found people with customs akin to those of the Kafirs already installed in the Hindu Kush when he got there - as Loude (1980: 152) also remarks is on the other hand documented by Arrian. In fact, the great Macedonian never entered Nuristan or Chitral, but, in his times, all the mountain people had polytheistic religions akin to those of the pre-Islamic Nuristani and the Kalasha (see infra).
} 


\section{The lost 'Greeks'}

Expelled from scientific writing the idea that the Kafirs were the descendants of Alexander's soldiers, or colonists, survived in popular literature - and it has recently been applied to the Kalasha of Chitral who, as the last polytheists of the Hindu Kush, ${ }^{15}$ tend to be seen as the rightful heirs of the non-Muslim cultures of Nuristan. The Kalasha have by now become a tourist attraction in Pakistan and there is no article in geographical or photographic magazines and no documentary film - of the many that have recently been produced that fails to report that the Kalasha claim descent from a group of soldiers of Alexander.

In fact, it can safely be stated that the idea does not belong to Kalasha traditional knowledge. Written sources on the Kalasha are much more recent than those concerning the Nuristani, because the attraction exerted by the independent Kafirs of the Hindu Kush was so great that for a time they monopolized the attention of researchers. Biddulph ([1880] 1986: 64), hardly mentions the Kalasha at all in his book, and Robertson, who travelled through their valleys on his way to Kafiristan, only pauses to comment that they are not the true independent Kafirs of the Hindu Kush because they are subject to the Mehtar of Chitral (Robertson [1896] 1974: 4). It is only in the mid 20th century that some knowledge of Kalasha culture was acquired through the works of Morgenstierne (1932, 1947, 1965, 1973a), Schomberg (1938), Siiger (1956, 1963, 1967, 1974), Friedrich (in Jettmar 1975), Snoy (1959, 1960, 1965, 1974), and Graziosi (1961, $2004,2007)^{16}$. All these scholars inquired about tales of origins but no mention of the Greeks or Alexander the Great ever appears in these early writings. ${ }^{17}$ Research was conducted mainly in Rumbur and

\footnotetext{
${ }^{15}$ Over 5000 speakers of the Kalasha language live today in the three valleys of Birir, Bumburet, and Rumbur in Lower Chitral, in the N.W.F.P. of Pakistan (cf. Decker 1992: 99-101). Of these the majority are polytheistic, but many have converted and the Muslim minority has been steadily increasing. Conversion, in the long run, usually leads also to a shift in language in favour of Khowar, the dominant language of Chitral (Cacopardo A.M. 1991, 1996; Decker Ib: 111-114).

${ }^{16}$ Graziosi's fieldnotes from 1955 and 1960 have been published in the Italian original in 2004 and 2007 (see bibliography).

17 Strangely enough, and quite interestingly, in one of his early writings Morgenstierne (1929: 311) mentions a supposed Alexandrian descent for the Chitralis, but not for the Kalasha.
} 
Bumburet. The oral traditions of those valleys spoke of a time when the Kalasha held sway over Chitral proper, and told of their defeat at the hands of the Rais Mehtars. Before those times, there was only a vague memory of a migration from the south-west under the leadership of a legendary ' $k i n g{ }^{18}$ called Shalak Shah who came from a mysterious land named Tsyam (Siiger 1956: 33-35). It is quite significant that, according to Nai Tarikh-i-Chitral - a historical work published in Urdu in 1962 but based on older materials (Holzwarth 1996: 117; Cacopardo \& Cacopardo 2001: 45) - the view that the Kalasha may be the descendants of some of the soldiers of Alexander's generals is due to some European historians (Murtaza [1962] 1982: 47).

Only in the course of the 1970s, when more intensive studies of Kalasha culture were carried out by a new generation of researchers, did such a narrative sporadically start to surface in Rumbur (Loude 1980: 156-162; Parkes 1983: 11-12), to all appearance through the initiative of one single renowned informant who worked with several ethnographers. In these accounts the legendary ancestor Shalak Shah, whom Siiger ${ }^{19}$ (1956: 33) depicts as an independent paramount king of the Kalasha, puts himself in the service of Sikander Mukadas, represented as a Muslim king of Yarkhun, in northern Chitral (Loude 1980: 166), who had a golden horn on his head (Ib: 158). The details of the story indicate that it was in all likelihood a borrowing from local Muslim lore rooted in medieval Islamic accounts - the same ones we found at the roots of the Alexandrian ascendancy of the Badakhshan kings - as both Loude (1980: 162) and Parkes (1983: 12) did not fail to notice. For what we could ascertain, the narrative was not part of common knowledge: no mention of an Alexandrian ascendancy was indeed made to the present author by other informants in 1973 and in 1977, at the time of his first visits, neither in Rumbur or in the other valleys.

\footnotetext{
${ }^{18}$ It is quite certain that the Kalasha never had a state-like political organization as the title of king would imply (Cacopardo A.M. forthcoming).

${ }^{19}$ The Danish scholar Halfdan Siiger was the first ethnographer of the Kalasha. He carried out his fieldwork in 1948 as a member of the Third Danish Expedition to Central Asia (Siiger 1956: 6). A previous visit paid to the Kalasha valleys by the Deutschen Hindukusch-Expedition of 1935 was very brief (Herrlich 1938). Linguistic work, though, had already been conducted in 1929 by Morgenstierne (1932), who had also collected some ethnographic data (e.g. Morgenstierne 1947).
} 
The narrative at any rate was given little credit by ethnographers, as far as its historical content was concerned; only a couple of non-scholarly works argue in favour of the Greek connection (Guillard 1974: 185-206; Afzal Khan 1975: 68). Apart from the absence of an established oral tradition, for researchers the results of linguistic investigation were indeed enough to dismiss the theory of a Greek ancestry of the Kalasha once and for all (e.g. Snoy 1959: 525 ${ }^{20}$; Jettmar 1975: 473; Loude \& Lièvre 1984: 25; cf. Morgenstierne 1929: 311). Since Morgenstierne's studies, it had been indeed shown that Kalashamon ( $\mathrm{kLL}^{\prime} \mathrm{aSa}$ mon $)^{21}$ - the language of the Kalasha - is a purely Indo-Aryan language that has a lot in common with Sanskrit and very little with Greek, apart from the distant IndoEuropean heritage. In this perspective any similarities between Kalashamon and Greek would be explained as deriving from the ancient vertical connection that passes through Sanskrit, and not from a horizontal one due to more recent contacts or migrations. Recent linguistic studies of Kalashamon have confirmed that view (Bashir 1988, 2003; Masica 1991: 21; Trail \& Cooper 1999; Heegård 2006).

In spite of this evidence an attempt to revive the theory of Greek origins was made in the 1990s by Gail H. Trail, from the Summer Institute of Linguistics, a private institution which has done important linguistic work in the Northern Areas of Pakistan. Her paper, presented at the 2nd Hindu Kush Cultural Conference (held in Chitral in 1990) was subsequently published in the Proceedings.

The theory Gail Trail presents as "quite plausible" is that the Kalasha could be the descendants of native Syrians who would have absorbed Greek culture during the reign of Seleucus I. Alexander's successor would have sent them "to far-away Greek Bactria to hold his territory there" and "to rid himself of possible internal revolt" while at the same time gaining "their lands in Syria to give to his retiring Greeks;" in alternative, or concomitantly, she suggests, "the Greek soldiers may have taken Syrian wives and settled in the far east in Seleucus' land-grant program when they retired" (Trail 1996: 364). One of the main arguments in support of this rather bold historical reconstruction is her identification of the mysterious homeland of

\footnotetext{
${ }^{20}$ Snoy does not relate here any Kalasha oral tradition, bur refers generally to the legend of the supposed Greek origins of the Kafirs of Nuristan, that by analogy could have been applied to the Kalasha.

${ }^{21}$ Capital letters indicate a retroflex articulation.
} 
Tsyam with Sham - which is the name for Syria in Arabic, Urdu, and Persian - on the basis of Morgenstierne's finding that Nuristani languages have the sound $t s$ where Sanskrit has $s h$. Though Kalasha is not a Nuristani language it does exhibit in some words this feature, which, for Gail Trail, "gives us a linguistic basis for examining the Kalasha as a people from Syria" (Ib: 360).

G. Trail then proceeds to clear the ground of the two major objections to the theory of the Greek origin of the Kalasha: that their language, as we have just seen, is purely Indic - which was fully confirmed also by the work of the Summer Institute of Linguistics (Trail \& Cooper 1999: xi-xiii) - and that the names of several of their gods are clearly connected to deities of the Vedic pantheon (Turner 1966: headwords 444, 6523, 6540, 8306, 8307, 8782, 10395; Cacopardo A.S. 2010: 342-343). The first and heaviest objection, she circumvents by proposing that the Kalasha must have changed language, adopting "the Northwest Prakrit long ago before they... became isolated groups in the side-valleys of Chitral." As for the affinities with the Vedic system, she considers them a fruit of the syncretistic tendencies of the Hellenized peoples which caused them to amalgamate "their own beliefs into Hinduism, Buddhism and Jainism when they came to India" (Ib.). To support her theory, G. Trail needs of course to suppose that "the Hindu Kush and Dardic areas were included in the former Persian satrapy of Bactria" that was conquered by Alexander and re-conquered by Seleucus; which she does on the basis of a brief passage in one of Jettmar's articles (Jettmar 1977: 419). She then seeks confirmation in Kalasha oral tradition and finds that Shalak Shah - the mythical 'king' mentioned above - can be identified with Seleucus through a linguistic analysis of the two names: "the Sanskritized form of Seleucus would reduce the vowels to $a$ 's and pronounce the $s$ as $s h$, the -us dropped later, becoming Shalak" (Trail 1996: 365). The argument leads thus to the "astounding" conclusion that "the story has "apparently survived almost 2300 years" in an incredibly clear form" (Ib.). A wealth of "corroborating details" - that we cannot examine here - follow, which concern epigraphical clues, place names, and Kalasha material culture and religion.

As can be seen, the theory is highly conjectural and its basis are weak. In the first place, as argued above, an oral tradition just cannot reach back that far. The linguistic argument, moreover, probably 
needs more cautious consideration: it must be kept in mind that Kalasha is not a Nuristani language and that its historical phonology has not developed along the same lines. But even if the argument were viable, Sham may more reasonably refer to Upper Chitral - as Morgenstierne (1932: 47) also believed - for, as we suggested (coincidentally resorting to the same linguistic argument used by G. Trail) in an article on Kalasha origins also published in the Proceedings of the 2nd Hindu Kush Conference,

... the name of this country may be connected with toponymes like Sanglechi Šam (northern Chitral), or Prasun Šim Gul for Chitral proper (Morgenstierne 1932: 47) perhaps related as Tucci also suggests (1977: 63, 80--81), to Śyanaraja, Šyama, Šyamaka, and most likely reflected in the Chinese Shê-mi, Shang-mi which Tucci, along with other scholars, tends to identify with northern Chitral (see also Jettmar 1977: 415-416, 423) (Cacopardo \& Cacopardo 1996: 308).

This would mean, we further suggested (cf. Cacopardo \& Cacopardo 1996: 308), that the tradition of the 'migration' from Tsyam simply reflects an ancient expulsion of a particular Kalasha group from some part of Northern Chitral, due to an expansion of the neighbouring Khowar speakers.

Furthermore, the idea of a group of emigrants from Syria who changed their language, is a mere conjecture. If those emigrants changed their language, how do we know that the migration ever took place? A doubtful identification of two place names seems too little, and the 'corroborating details' we could not list do not give enough support. Moreover there is really no proof that the Achaemenian satrapy of Bactria extended to the heart of the Hindu Kush. In the passage quoted by G. Trail, Jettmar states that "under Arthaxerxes II all Achaemenid dependencies down to the river Indus were included in a larger Bactrian satrapy" (Jettmar 1977: 419); but this most likely referred to the plains, not to the mountains. In fact, Jettmar himself states in another work that "this area [the Hindu Kush] never formed an integral part of any of the Great Empires of Asia" (Jettmar 1974a: IX). As for Alexander, it seems quite certain that he never advanced into the mountains further north of Bajaur and Swat (Stein [1929] 1996; Caroe 1958: 43-57; cf. Edelberg \& Jones 1979: 34), as is corroborated also by Timur Laing's statement reported above where he recalls that not even the great Macedonian had subdued the Kafirs. 
As for the identification of the name Shalak Shah with Seleucus, even if linguistically viable, it is not very meaningful. Names travel far, as we all know by our own personal experience.

What can we infer then from Kalasha oral traditions? After an initial period of fieldwork in Rumbur in 1973 (Cacopardo \& Cacopardo 1977) and 1977, starting from 1989 the author has carried out with Alberto M. Cacopardo an extensive survey of oral traditions in Southern Chitral (Cacopardo A.M. 1991, 1996; Cacopardo \& Cacopardo 1992, 1996; Cacopardo A.S. 1991, 1996). The project concerned the converted Kalasha communities of the area of Drosh, those of the two valleys of Jinjeret Kuh and Urtsun, as well as other linguistic minorities of the region (see fig. 1 ). ${ }^{22}$ More recently, in 2006, an investigation of oral traditions was conducted by the author in Birir and by Alberto Cacopardo in Upper Chitral.

The picture that emerged is interesting and quite complex. In the first place, it is best to make clear that in all these communities no mention was ever made of Alexander the Great or of a Greek origin. In the second place, one thing seems certain: that it is not correct to speak of any single tradition of origins for the Kalasha as a whole. Tsyam, as an original homeland, is mentioned only in Bumburet and Rumbur $^{23}$ and its basis is seemingly in the myth of the god Balimain, who is believed to come from Tsyam during the winter solstice festival, and in the chant of a single ritual, performed in spring when the weather is "unreasonably bad" in which the women, making no mention of Shalak Shah, just threaten to go to Tsyam if the rain does not stop (Maggi 2001: 214-216).

The names of Tsyam and of Shalak Shah as a founding ancestor, were not mentioned in any other Kalasha community.

\footnotetext{
22 The Dameli of Damel valley; the Palula of Ashret and Biyori; the Gawar of Arandù, the Jashi of Badugal and Gawardesh. The data available on the pre-Islamic religions of these groups were quite scant, but nevertheless enough to indicate clearly that they were akin to that of the Kalasha (Cacopardo \& Cacopardo 2001).

${ }^{23}$ Indeed even in Rumbur and Bumburet the tradition was not apparently of general knowledge: in a text taken down by Wazir Ali Shah, Lamson, a respected elder in Siiger's time, referring to the early ancestors of the Kalasha, declares that he had "no knowledge where these people came from and when, and probably they were the real inhabitants (bhumk'i $=$ of the same soil) of that valley." The text, included in the Siiger Archives, was kindly put at my disposal by Jean-Yves Loude.
} 


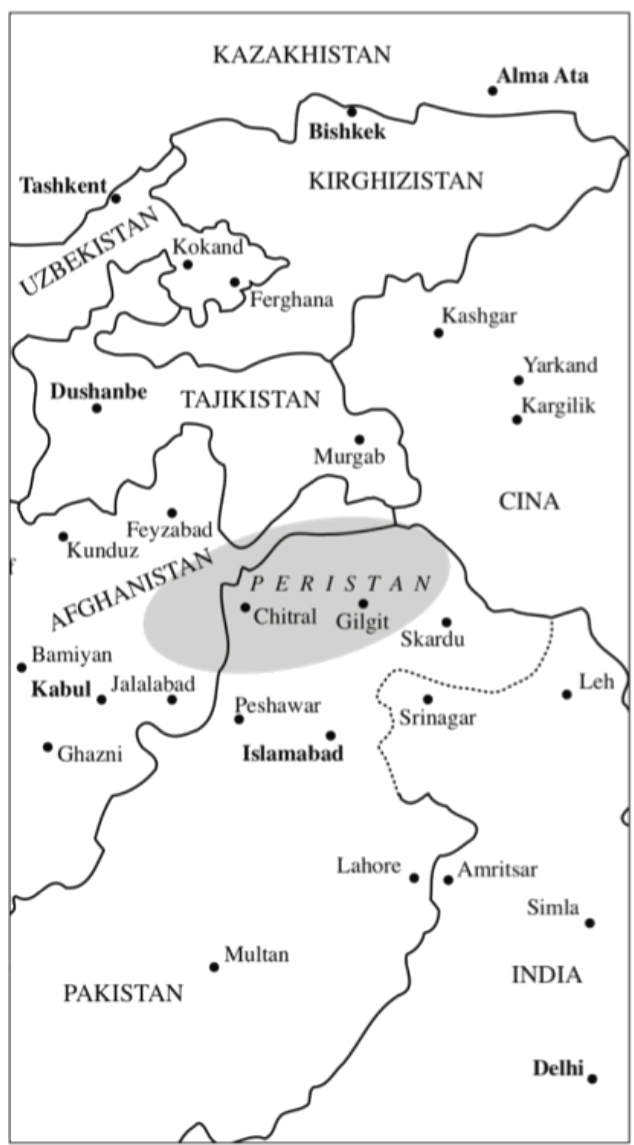

Figure 1. Chitral and the Afghan border areas

We recorded a myriad of different stories, mostly pertaining to single lineages or lineage groups. Even within the same community we have found different traditions of origin: in Birir one of the largest lines of descent claims to have come from the west, from Afghan Nuristan, another one supposedly came from the Shishi Kuh valley that lies east of Drosh, while three or four lineages are styled bhumk'i, because they are believed to be aborigines of the valley, and they have preserved no memory of a former residence or migration. The same is true of Bumburet: some of the lineages there are believed to descend from the same apical ancestor as those of Rumbur (the Rachikoshdari and Bumburdari of Krakar, the Rajawaidari of Batrik and possibly the 
Budadari of Kandarisar) and may therefore be connected with the epic of Shalak Shah, while the ancestors of others are said to have come from Yasin (the Turikdari of Daras Guru), or from the Chitral area (the Bulasingdari and the Bazikdari of Bruhn), while some (the Aspaindari and Baramukdari of Anish) are again believed to be bhumk'i. Not even in very small communities such as Urtsun and Jinjeret Kuh, did we find a single tradition of origins. In the latter, the main group of descent is said to have its origins in Khurkashande, just south of Chitral, while two small lineages are believed to have come from Bashgal; in the former, the traditions of all lineages tell of a migration from Nuristan, but from different areas of the region. Only in Rumbur have we found a single tradition of origin, because there the whole population is believed to descend from one and the same apical ancestor.

The general impression is that there has been a movement of groups of refugees from the main Chitral valley to the side valleys, in concomitance with the advance of Islam in Chitral, as well as some immigration from Nuristan. The latter may have taken place at the time when the Kati speakers who now inhabit Bashgal migrated there from Western Nuristan, an event related in their own traditions that can be taken as quite historical, probably having taken place no earlier than the 16th century (Cacopardo A.M. forthcoming). That "the Kalash also held some parts of Bashgal" is an idea that we find in NaiTarikh-i-Chitral (Murtaza [1962] 1982: 44-45) but is not confirmed by Kati oral traditions, that mention instead the Jashi (Cacopardo \& Cacopardo 2001: 173-225) as the former population of that valley; it could be that the immigrants from Nuristan were actually Jashi who later adopted the Kalasha language. As for the population movements from the Chitral area and the main valley in general, they probably took place some time later and must have been caused in all likelihood by the Muslim conquest of Southern Chitral. Thanks to the work of Wolfgang Holzwarth (1996), which we have tried to complement through the investigation of oral traditions, some new light has been shed on the chronology of the Islamization of Chitral. It is now quite certain that the defeat of the Kalasha by the Rais Muslim rulers took place some time between the end of the 17th and the beginning of the 18th century (Cacopardo \& Cacopardo 2001: 50). The oral traditions we recorded indicate that when the area of Chitral, and then that of Drosh, fell in Muslim hands, some refugees escaped to the side 
valleys and settled there. The Muslim conquerors, however, were not the only agents of the downfall of the Kalasha. The oral traditions of the Palula of Ashret and Biyori, of the Dameli, and of the Gawar of Arandu, all agree in stating that their territories were formerly inhabited by a Kalasha population (Cacopardo \& Cacopardo 2001); this confirms a long-standing local tradition - supported by the famous Luli song (Morgenstierne 1973a: 57-65) which mentions all the places where the Kalasha spring festival of Joshi was celebrated according to which the area formerly occupied by the Kalasha extended from Ludkho as far south as Asmar (Fig. 1). However, since none of the lineages of the five right-bank valleys have traditions of a migration from those areas of Southern Chitral, we must assume that those Kalasha communities were either exterminated or assimilated.

As we can see Kalasha oral traditions only tell of migrations from nearby areas reflecting events that cannot go back in time any further than four centuries at the most. Here we must highlight a difference between narratives such as the ones just recalled, that appear to have some historical foundation, and the founding Rumbur tale of the arrival from Tsyam under the lead of Shalak Shah, which seems to belong instead to a timeless mythical past. We have found however in Upper Chitral a possible trace of that legendary ancestor: the construction of an ancient irrigation channel in the area of Mastuj was ascribed by a local informant to a Kalasha ancestor called Salàk. And it is interesting to note here that Morgenstierne's privileged informant Mahmad Isa believed that Kalasha territory formerly extended indeed as far as Mastuj (Morgenstierne 1965: 188). This finding is not enough of course to draw any conclusions, but it seems to give some corroboration to our hypothesis - quoted above (Cacopardo \& Cacopardo 1996) - that the mythical land of Tsyam may possibly be identified with Upper Chitral. A hypothesis that Parkes (1991: 78, fn.) had also independently formulated.

The data reported above seem to indicate that in the case of the Kalasha, rather than of one great migration from some distant homeland we should think of many small migratory movements following the contraction of the Kalasha area under the pressure of neighbouring peoples and of the ascending Muslim power. It is likely therefore that the Kalasha have long been more or less where they are now, as linguistic data, on the other hand, strongly indicate: already Morgenstierne noted that Kalasha and Khowar are closely related 
languages for which common proto-forms can even at times be reconstructed; which means that the speakers of the two languages must have been in close contact for a long span of time and that "probably the two languages belong to the first wave of Indo-Aryan immigrants from the south" (Morgenstierne 1932: 51; cf. Siiger 1956: 34). Their presence in Chitral could possibly even date, therefore, to the 2nd millennium B.C. (Mallory 1989: 47-48).

To conclude, there is really no grounds on which the idea of a Greek origin of the Kalasha can be based. ${ }^{24}$

If the Kalasha are not intruders in the Hindu Kush, let us try to see then what is their place in the broader context of the Hindu Kush cultures.

\section{The Kalasha and the pre-Islamic world of the Hindu Kush}

Almost fifteen years ago, in the middle of the 1990s, a little revolution came about in Hindu Kush studies. It was initiated by the German historian Wolfgang Holzwarth with an essay specifically concerning Chitral history that was also published in 1996 in the Proceedings of the 2nd International Hindu Kush Cultural Conference.

The issue at stake was the pre-Muslim cultural and religious history of the Hindu Kush and the time and circumstances of the advent of Islam. It was generally believed that the conversion of the mountainous country stretching from Afghan Nuristan to the borders of Kashmir - the area that we have elsewhere called Peristan ${ }^{25}$ (see fig. 2) - was something quite ancient, dating back several centuries at least (Biddulph [1880] 1986: 117; Stein 1928: 25; Lorimer 1929: 508; Schomberg 1938: 263; Jettmar 1975: 202-205, 1996: 90; Loude \& Lièvre 1984: 28); apart of course from the case of Nuristan, which notoriously resisted Islam until the end of the 19th century.

\footnotetext{
${ }^{24}$ Genetic data confirm this conclusion. Recent research has found no Greek genetic input in the Kalasha population (Mansoor A, Mazhar K, Khaliq S. et al. 2004; Firasat S., Khaliq S., Mohyuddin A., et al. 2007).

${ }^{25}$ We believe this area corresponds really to Marco Polo's 'Bolor'. But to avoid getting entangled in the thorny debates concerning this term, we resorted to a name of pure fantasy referring to the belief, still widespread in the region, in the spirits of the mountains (peri or pari) (Cacopardo \& Cacopardo 2001: 13-19).
} 


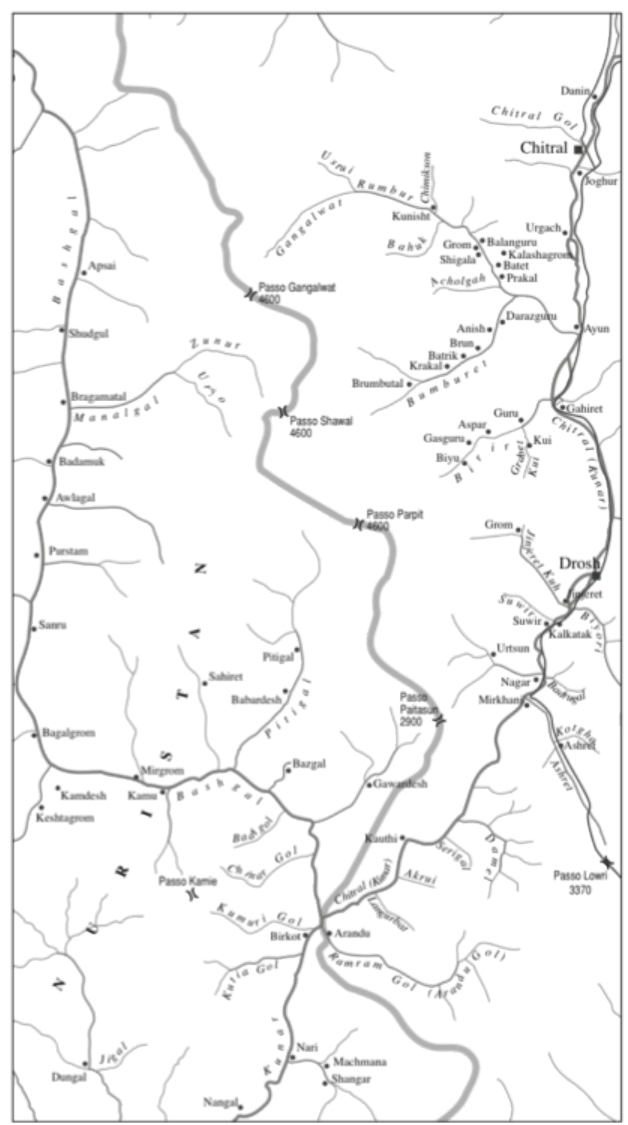

Figure 2. The area we refer to as Peristan.

Biddulph believed, due to the many archaeological remains, that the country had formerly been Buddhist starting from the 2nd century B.C. Buddhism would have been superseded by a wave of Hinduism brought by Shina speakers coming from the South, and Hinduism would have finally given way to Islam between the 13th and the 15th century A.D.; a chronology he proposed on the basis of local reports and of the genealogies of the ruling families (cf. Holzwarth 2006: 184-185). Biddulph's book was very influential and his view remained prevalent for a long time.

The topic of the pre-Islamic cultures of Peristan is indeed so vast that Western scholars usually avoided to broach it, concentrating instead on the particular communities that were the subject of their 
researches. Only Jettmar (1975) decided to deal with the issue in full. His latest view is spelled out in an essay also published - like G. Trail's, Holzwarth's, and our own - in the Proceedings of the 2nd H.K. Cultural Conference.

At the end of his long carrier, Jettmar (1996: 84-85) still did not doubt Biddulph's conviction that there had been a time when Buddhism was preponderant in the mountains, though for Chitral, he noted, evidence was rather uncertain. His important discovery of a wealth of Buddhist petroglyphs in the Indus valley (Jettmar 1982) appeared to confirm that view. On the basis of those findings which did not include "normal Hinduistic symbols," however, he questioned the second part of Biddulph's historical reconstruction, arguing that "there was not a general Hinduistic period in the history of Gilgit, but the regime of a particular sect" (Ib: 89). This, he conjectured, may have been that of the Saura, a Hindu religious group devoted to sunworship, originally centred in Multan, which spread to the mountains where it supposedly found fertile grounds due to an earlier solar cult introduced there by the Hephtalites. Between this "Buddhist period with Hinduistic opposition" (Ib: 89) that ended in his view sometime in the 1200 s A.D. and the supposed final victory of Islam after 1500 A.D., there was a gap with "no clear evidence revealing the 'official' religion" (Ib: 90) prevailing in the area. This gap he ventured to fill with the "rather daring hypothesis" that a "new sort of tribal religion," a "medieval reformed paganism," became the basis of "a sort of resistance movement" fed mainly, but not only, by a pastoral ideology brought by Shin immigrants from the south, to which he connects the religion of the Kalasha, though not that of the "Great Kafirs" of Nuristan (Jettmar 1996: 86-93). This revival would have come "in full flower" just at the final dawning of Islam. The many traces of pagan cults that not only the early British scholars, but he himself and his associates had found in Dardistan, as well as the Kalasha religion, would therefore belong to this late backlash of paganism before its final defeat.

The revolution initiated by Holzwarth - on the basis of a wealth of Islamic historical sources coming from the countries surrounding Peristan - not only completely changed the traditional picture based on Biddulph's book, but contradicted also its revised version proposed in Jettmar's latest work. Though Jettmar (1996: 90) partially objected to Holzwarth's conclusions, it is quite clear now that Islam first, and 
fleetingly, entered the mountains from the North only in the $1500 \mathrm{~s}$ (Holzwarth 2006: 173-174), and that it took centuries to become the established religion of the region. Earlier dates proposed by local authors like Ghulam Murtaza for Chitral or Hashmatullah Khan for Gilgit turned out to be the fruit of fabrications (Holzwarth 1996), seemingly fostered by the desire to present impeccable Islamic pedigrees dating back in time as far as possible. The genealogy of the Katur Mehtars of Chitral, for example, had evidently been stretched over a span of time it could not possibly cover (Cacopardo \& Cacopardo 2001: 51-53). Biddulph and the other early British writers had fallen prey to such avowals, as did also the more recent researchers quoted above.

On the impulse of Holzwarth's work the data collected by Alberto M. Cacopardo and the author in Southern Chitral in the course of the 1990s were examined in the light of a detailed analysis of all sources concerning Peristan available in Western European languages (Cacopardo \& Cacopardo 2001). These include works of many Asian chroniclers which have been translated into English, as well as a wide range of non translated sources made available by Holzwarth's researches.

The picture emerging from this work is that, though the first Islamic inroads started as we have just seen in the 1500 s, still three centuries later the peoples of the Hindu Kush chain from Nuristan to Gilgit were still largely unconverted. Though the ruling dynasties had pleaded allegiance to Islam some time earlier - at least in Chitral, if not in Hunza or Gilgit - it was only from the early 19th century that Islam really began to spread to the bulk of the population: through the efforts of the Kashmiri governor Nathu Shah in the area of Gilgit, and through the pressure of Pathan missionaries in the southern belt of our area, i.e. in Indus Kohistan, Swat Kohistan, Dir Kohistan, Southern Chitral, and the Kunar area. It is quite clear also that the pre-Islamic religions of those peoples were not a "medieval reformed paganism," as Jettmar suggested in his latest writings, but were rather the ancient religions of the area which had never ceased to be practiced. The materials presented (Cacopardo \& Cacopardo 2001: 25-54) indeed show not only that the Islamization of Peristan is a much more recent event than it had been previously thought, but also that neither Buddhism nor Hinduism ever gained a permanent foothold in the mountains. The presence of Buddhism is indeed attested in Eastern 
Peristan by archaeological remains and by the many rock documents of the Indus valley, but it is almost certain that it remained confined to the elites of the statelets which controlled the arduous route (Fussman 1988) connecting India to Central Asia through the Indus valley (cf. Tucci 1963). As for Hinduism it is even more certain that it never really managed to make an inroad in the Hindu Kush and that, as Fussman (1976: 205; 1977: 25) wrote over 30 years ago, the Dardic and Kafiri speaking peoples remained outside the reach of Brahmanism. That the autochthonous religions of Peristan remained for centuries outside of the fold of the great religions of India, is in fact just as surprising as their long-term resistance to Islam.

The religion of the Kalasha and the pre-Islamic religions of Dardistan, therefore, can hardly be considered a late by-product in the religious history of the Indian subcontinent, as Jettmar would want them. All seems to indicate, in contrast, that they should rather be seen, like those of Nuristan, as an independent development from an early Indo-Aryan - or possibly, according to Witzel (2004: 614), even Indo-Iranian - basis, harking back to pre-Vedic times (cf. Parkes 1987: 582). An independent development that in former times was, of course, probably more in touch with events in the plains than it happened to be after it was encircled by Islam: echoes from the civilizations surrounding it probably reached Peristan regularly when Buddhism and Hinduism prevailed in the plains, but for a great part of the region at least, they were in all likelihood only distant echoes.

Nor can Kalasha culture consequently be viewed as an island in the broader context of the Hindu Kush, with no ties with the cultures surrounding it. In contrast, it is rather to be seen as the last living example of a cultural and religious complex that was formerly spread throughout the Hindu Kush/Karakorum chain; reaching as far as the borders of Ladakh in the East ${ }^{26}$ and extending to the footholds of the mountains in the South, and to the northern slopes of the main ridge in the North. In pre-Islamic times this region was the home of a constellation of archaic cultures featuring polytheistic religious systems that certainly differed in many traits, such as the names of the gods or the morphology of cyclical festivals, but which had also many

\footnotetext{
${ }^{26}$ Indeed there are indications that this ancient culture area possibly extended in the past even further East, to include at least the Pahari people of Himachal and Uttar Pradesh (Cacopardo, A.S. 2010: 350-356). For linguistic data supporting this hypothesis see Zoller 2010: 248-49.
} 
common elements. A list of such traits that Fussman (1983: 195) compiled with reference to the Nuristani, the Pashai, and the Kalasha only, can in fact be applied to the whole of Peristan. These traits include the organization of the agro-pastoral economy, the division of labour between genders, canons of architecture and decoration, the use of wine, the belief in the purifying power of juniper, the existence of shamans. To these, lineage exogamy can be added, as well as the social division between a large majority of free men and a minority of artisan-serfs. Not only, what really appears to bind together this complex constellation of cultures is the fact that they are based on a common pastoral ideology centred around a fundamental pure/impure polarity, which opposes a masculine sphere of goat-herding to which positive values such as social solidarity are connected, to an impure feminine sphere closer to agriculture seen as the realm of more individualistic, family orientated tendencies. This basic unity of the area had indeed been perceived by Jettmar in his early works, when he remarked that the region - which he proposed then to call Greater Kafiristan - "shows a multiplicity of social and religious systems which can be regarded as variants of a single structure" (Jettmar 1965: 117).

All elements indicate that the Kalasha are an integral part of the cultural fabric of the Hindu Kush, and it is only their long-term resistance to Islam that now sets them apart from the other populations of the chain. Just as their language is closely allied to the other languages of the area, so is their culture closely connected to the former pre-Islamic cultures of the region.

The region we called Peristan, in pre-Islamic times formed indeed a basically homogenous culture area to which the Kalasha fully belonged. This shows again that they cannot therefore be seen as descendants of the Greeks of Asia. Neither of Alexander's troops nor of colonists from the Greco-Bactrian and Indo-Greek kingdoms established by his successors first on the river Oxus and then in Gandhara between the 3 rd century B.C. and the 1 st century A.D. ${ }^{27}$

\footnotetext{
${ }^{27}$ Which does not mean, of course, that we can altogether rule out the possibility that some faint cultural influence from those kingdoms - like similar influences from other cultural centres that developed through the centuries in the plains - may have reached the cultural world of Peristan.
} 


\section{The pre-Islamic cultures of Peristan: some comparative suggestions}

It may be useful at this point to set for a moment aside the issue of Kalasha origins and consider Kalasha religion in itself in a broader comparative perspective to detect affinities and similarities, always keeping in mind that we see it as pretty much representative of the pre-Islamic world of Peristan. The question is where to place this peculiar constellation of cultures in relation to the Asian and to the European world.

Though some scholars highlight Iranian connections (Tucci 1963: 158; Jettmar 1974b; Gnoli 1980: 70-74) - which indeed deserve further investigation - the view already expressed in the 1970s by Fussman (1977: 25; cf. Buddruss 1973: 39), that the preIslamic cultures of the Hindu Kush basically belonged to the Indian world, as their languages do, seems still valid. Apart from manifest reminiscences of the gods of the Vedic pantheon in the names of Kalasha and Nuristani divinities, among the traits listed above there are some that specifically appear to connect Peristan to India. In the first place the fundamental exogamic rule governing the formation of lineages, which reminds closely of the Indian sapinda system. In the second place, the even more fundamental pure/impure polarity, on which the Indian caste system is based. The hierarchy that according to Louis Dumont ([1966] 1979) this opposition implies, among the Kalasha finds expression mainly in gender relations (Cacopardo, A.M. forthcoming), with the women, expectedly, on the impure and therefore inferior side. But not only in gender relations; for the pureimpure polarity provided the idiom for another form of inequality: at the margin of Kalasha society, and of the other societies of Peristan, there was formerly a class of serfs and artisans who were deemed impure and with whom commensality was not allowed (Cacopardo \& Cacopardo 2001: 42-44). We may say therefore that if there is no trace among the Kalasha and in the other cultures of Peristan of a hierarchical structure like that of the caste system (Ib.) (pace Fussman 1977: 60-64), the idea itself of caste, though at a very embryonic stage, did apparently exist.

However, while much seems to point towards India, there is something distinctly European in the atmosphere of the Kalasha valleys. An impalpable sensation that caused Fosco Maraini - the 
author of an impressionistic but highly valuable account of a visit to Bumburet - to remark that everything in the valley reminded him of home and that whatever was strange, had the taste of something ancient, rather than exotic (Maraini [1963] 1997: 142).

Apart from this impressionistic element, some cultural affinities with ancient Europe seem to exist. If the Kalasha pantheon is quite certainly wholly Indo-Aryan, the ritual cycle appears to have more affinities with what we find in Europe than with the festival cycles of India. Though the ritual cycles of pagan Europe have been shattered and subsumed in the Christian calendar, the winter ritual sequence of the Kalasha, in particular, appears to be built on a model that is roughly discernible in the European winter sequence starting with All Saints and ending with Carnival. The temporal succession of the three winter feasts of Chaumos, Lagaur and Salgherek in Birir (Cacopardo, A.S. 2008, 2010), for example, corresponds pretty much to the sequence including Christmas, the Epiphany, Sant'Antonio Abate and Candelora highlighted by Cardini (1995: 191) for Italy. Since ritual cycles are closely connected to economic activities, this is surely in part due to the similar climate and environment, very different from that of the monsoon planes and hills of India. But only in part. There are parallels also in the ritual events, which include the descent of the dead, the arrival of a god and of another benevolent being; while Carnival hosts the rituals of inversion and the orgiastic elements that are characteristic of Chaumos (Wutt 1983; Loude \& Lièvre 1984; Cacopardo \& Cacopardo 1989; Snoy 2008; Cacopardo, A.S. 2008, 2010). ${ }^{28}$ These are of course elements of a ritual complex quite typical of New Year Festivals in many societies (Eliade [1949] 1968: 92-99), but a few elements appear to indicate some more specific affinities. The use of juniper smoke for purification, for example, is documented in the French Alps and in the British Isles (Hutton [1996] 2001: 42, 45; Van Gennep 1988: 3516-3517); animal figures of baked bread like the ones made for Chaumos are made in Russia to favour the reproduction of animals (Propp [1963] 1978: 66-67); the custom of decorating buildings with greenery, as is done in Birir for Lagaur, is a characteristic trait of European December festivals from pagan times

${ }^{28}$ These, especially, are quite marginal in India (Dumont [1966] 1979: 342) where they appear only in the Holi festival (McKim Marriott 1968), which is mostly confined to the North. 
to the Middle Ages (Lévi Strauss [1952] 1995: 67; cf. Hutton [1996] 2001: 34-35; Van Gennep 1988: 3492); the ritual use of willow is documented again in Russia (Propp [1963] 1978: 112-114); the Epiphany used to be "the feast of beans" (Bakhtin [1965] 1984: 219) like the Kalasha dahu tat'u; the mistletoe, an augural plant in Europe, is used in Birir in the closing rite of Chaumos. Is also perhaps of some relevance the circumstance noted by Snoy (2008: 43), that the tonic system of Kalasha music is similar to the European one, because it lacks the numerous intermediate tones typical of Indian music.

These however are only random parallels: a detailed study of European folk traditions would be needed to draw some conclusions.

\section{Balima-In and Dionysos}

An interesting comparison - which had attracted the attention also of Adolf Friedrich, one of the first ethnographers of the Kalasha (Buddruss \& Snoy 2008: 11) - specifically concerning Greece, that we may try to outline here is that with the cult of the god Dionysos. His counterpart among the Kalasha would be the visiting god of the Rumbur/Bumburet Chaumos, Balimain. The name of this divinity connects it directly to Indra, the ancient tutelary god of the IndoAryans, to which many Vedic hymns are dedicated (Stutley \& Stutley [1977] 1980: 170). Its most likely etymology, in my opinion, is Balima-In, where Balima (bal'ima) would be an epithet meaning 'powerful' borrowed from Kati (Morgenstierne 1951: 180, 184; cf. Jettmar 1975: 358), while In stands for Indra. In fact the Kalasha themselves address Balimain as Indr in songs and invocations. As a solar deity who defeats the obscurity of winter, bringing fertility, his figure seems indeed to coincide with that of the Vedic god; but in some respects, and for the characteristics of his cult, he recalls also Dionysos.

The personality of Balima-In is of course much hazier than that of the Greek god. Only a couple of myths are told about him. But even from this mythological poverty several traits emerge that approach him to Dionysos. In the first place, like Dionysos Balima-In is a visiting god. His visit is brief because he departs at the end of Chaumos, while the god of wine was believed to stay for the winter on earth to leave only in spring (Eliade [1975] 1979: 390); but in both cases we have a god who comes in the dark time of the year, and then 
goes. In the second place, Balima-In, like Dionysos, is a hermaphrodite: he is represented as male on the right side and female on the left side, integrating in his person the two opposed poles (Jettmar 1975: 354). The same is said of Dionysos who has a masculine and an effeminate form (Daniélou [1979] 1980: 59) and whose "spirit joins the opposed poles" (Otto [1933] 2006: 148, 129) and whose "nature expresses the paradoxical unity of life and death" (Eliade [1975] 1979: 402). In the third place, both deities are gods of fertility. Dionysos was seen as the god of trees, and especially of those that bear fruits; he was really the god of life eternally renovating itself (Eliade Ib: 393; Otto Ib: 165; Merkelbach [1988] 1991: 18); the prayers with which Balimain is invoked ask for "seed of offspring and seed of wheat" (putr bi zhe gum bi). Both gods, furthermore, arrive when the wine vats are opened for the first time. In the Kalasha valleys this is done for the winter solstice festival, while in ancient Greece it was done in February-March for the Anthesteriae which, like Chaumos, is a New Year feast (Spineto 2005). The fact that the festival during which Balimain descends on Earth, is the time when wine is consumed seems a clear enough indication of his connection with the vine and its fruit. Even more explicit, however, is his connection with wheat, because he is believed to have introduced the plant among men (Jettmar 1975: 354). Such a connection is weaker in Dionysos, but it nevertheless exists: the god of wine is also believed "to have been the first to yoke oxen to the plough, which before had been dragged by hand alone" (Frazer [1922] 1987: 387-388). Moreover, the myth of the first arrival of both gods tells of an initial rejection followed by the punishment of the guilty ones. Balimain was ill-treated by the people of Kandarisar village, who set their dogs at him thinking he was a robber, and they were incinerated by a bolt of lightning flashed from his whip (Schomberg 1938: 184; Shah 1974: 78; Jettmar 1975: 353-354). The corresponding myths concerning Dionysos are so well known that we do not need to list them here; we shall only recall the horrendous death of the king Penteus who was torn to pieces by the Menads for having forbidden his cult (Otto [1933] 2006: 82; cf. Eliade [1975] 1979: 388-389). It is interesting also that, according to Eliade (Ib: 400-402) - who follows here a suggestion already made by Jeanmaire ([1951] 1972: 386-388) - at the bottom of the myth of the "passion and resurrection of the child Dionysos-Zagreos" there is an archaic, forgotten, initiation ritual. In 
the scene of the Titans with their faces smeared with white chalk for disguise, killing, tearing to pieces, cooking and eating the body of the divine child, he recognizes an initiation scenery. The death of the god and the following resurrection for him is a transposition of the symbolic death and rebirth of the initiate to the Dionysian Mysteries. In the case of the Kalasha, the initiation scenery is quite explicit, as initiations are one of the main events of Chaumos. Accordingly, it would seem, Balimain does not die: the novices are there to go through the symbolic ordeal. He is a visiting god, but not, like Dionysos, a god who dies and resurrects. Finally we can detect in Balimain something of the horrific side of the cult of Dionysos, impersonated by the Menads who in their fury devoured animals and men, and especially children, ripping them off their mothers' arms: according to the myth, Balimain, on his first descent, took away with him the children gathered for initiation in his holy place and never brought them back; so that now only older boys are sent to his sanctuary to perform the ritual hailing his arrival (Jettmar 1975: 354).

Though the hazy myth of Balimain cannot certainly be compared with the wealth of mythology that developed around the figure of Dionysos, the two gods seem to have a fair number of traits in common. How can they be explained?

A connection with India is among the many peculiarities that set Dionysos quite apart from the other gods of the Olympus (cf. Eliade [1975] 1979: 402). The "conquest" of India and the triumphant return of the god are well known themes. There is a however an earlier journey Dionysos took across Asia, which is not always recalled. According to the different - and not always consistent - traditions, Dionysos was actually born in India and had travelled to Greece after a childhood spent in Nysa or on Mount Meros. Euripides is the first author to mention this journey (Grossato 2008: 278). Grossato (Ib: 280-281) suggests that the myth of the Indian origin of Dionysos can be very reasonably explained if we consider that the route followed by the god, on the basis of the available archaeological and ethnobotanical evidence, appears to coincide pretty much with the route along which the vine and viticulture expanded west from Central Asia. At the present state of research it seems that the cultivation of the vine first developed south of the Caucasus where the wild sub-species of the vitis vinifera Linnei, the vine at the origin of $99 \%$ of the wine produced today, still prospers. This vine, however, is found as far east 
as Tajikistan, i.e. just north of the Hindu Kush. The itinerary that was later to become the famed Silk-route, Grossato (Ib.) further suggests, may earlier have been the Wine-route.

If we consider that an autochthonous vine - vitis nuristanica Vassilcz - is found in Nuristan (Neubauer 1974; Edelberg \& Jones 1979: 35$)^{29}$ and that the southern slopes of the chain would have been just as well (if not better) fit for the production of grapes (cf. Olmo 2000), it appears that our area may be, if not the very first, at least one of the first wine-producing zones in Eurasia; that Nysa was in the Paropamisos, i.e. the Hindu Kush, is on the other hand part of the myth. The circumstance that the goat is one of the two animals more closely associated with Dionysos could be taken as a further indication in this direction: the Hindu Kush is apparently the home of the breed of wild goat which is considered to be the progenitor of all domestic goats (Snoy 1959: 528). In this context, I believe, the similarities between Balimain and Dionysos could be explained by their connection with wine. Rather than of an influence reaching the Hindu Kush from Greece, no matter when, I believe we should think in this case of the exact opposite, i.e. an Asian influence reaching Greece. The route followed by Dionysos would in this case refer to the itinerary along which viticulture spread west. This does not imply of course that the figure of Dionysos should be seen as a direct development of that of Balimain. It may be, rather, that both divine figures may stem from a remote religious humus common to Greece and the Indian world, that may be also at the roots of Sivaism. Like Balimain, Siva too is indeed represented at times as male on the right side and female on the left side (Daniélou [1979] 1980: 60). Similarities between Siva and Dionysos have been highlighted and discussed by some authors (e.g. Kirfel 1953; Daniélou Ib.), but the issue, as noted by Bernard Sergent (1997: 321-322), needs further research. In his view Siva is a "rigorous" equivalent of Dionysos, to the point that he sees behind the two gods the profile of an ancient Indo-European divinity, a god subversive of social order (Ib: 324$)$, as can indeed be said for some aspects of the cult of Balima-In. ${ }^{30}$

\footnotetext{
${ }^{29}$ The wild grape populations of Nuristan need further study, for the dioecy (the allocation in distinct individuals of the male and female sexual organs) expected in wild vines has not been verified (Olmo 2000: 36).

${ }^{30}$ It may be interesting to note here that, according to the theory of the Soviet authors Gramkrelidze and Ivanov, which anticipates the Indo-European migrations to about
} 
But we are here in the slippery realm of conjectures. What we can state with some certainty is that we do not need to resort to the idea of some comparatively 'recent' (so to say) Greek influence to explain the parallelisms that may possibly be traced between some aspects of Kalasha religion and the pre-Christian world of Europe. It is much further back in the past that we must set our gaze, possibly into the common proto-Indo-European background. The Kalasha indeed bring us back to the roots of an event - the Indo-European migrations - which had a much greater impact on the subsequent history of humanity than the - comparatively - rather fleeting triumphs of the great Macedonian. To be faced, in the 3rd millennium of the Christian Era, with what Maraini ([1963] 1997: 159) called "the only true survival of the original religiosity of the Indo-European peoples" is indeed a wonder even greater than would have been the discovery of a stray group of Greeks in the heart of Asia.

\section{References}

Afridi Banat Gul (1988). Baltistan in History. Emjays Books International. Peshawar.

Alder G.J. (1963). British India's Northern Frontier 1865-95. A Study in Imperial Policy. Longmans. London.

Afzal Khan Mohammed (1975). Chitral and Kafiristan. Peshawar.

Babur Badshah Ghazi M. Zahirud-Din (1921). Babur-nama (Memoirs of Babur). Translated from the original Turki text by A.S. Beveridge. Repr. New Delhi, 1990.

Bakhtin M. (1984). Rabelais and His World. Indiana University Press. Bloomington. Or. ed. Moscow, 1965.

Bashir E. (1988). Topics in Kalasha syntax: An areal and typological perspective. Ph.D. Dissertation. University of Michigan. Ann Arbor.

5000 B.C., the Proto-Indo-Europeans may have been the first producers of wine (in McGovern [2003] 2004: 46). 
Bashir E. (2003). Dardic. In G. Cardona \& Dhanesh Jain (eds), The Indo-Aryan Languages. Routledge. London.

Bashir E. \& Israr-ud-Din, eds (1996). Proceedings of the Second international Hindukush Cultural Conference. Oxford University Press. Karachi.

Bellew H.W. (1891). An Inquiry into the Ethnography of Afghanistan. London. Repr. Graz, 1973.

Biddulph J. (1880). Tribes of the Hindoo Koosh. Calcutta. Repr. Peshawar, 1986.

Buddruss G. (1973). Archaisms in Some Modern Northwestern IndoAryan languages. In Embassy of the Federal Republic of Germany (ed), German Scholars on India. Vol. 1. Varanasi, $31-49$.

Buddruss G. \& P. Snoy (2008) The German Hindu Kush Expedition (DHE) 1955-56. In Journal of Asian Civilizations, XXXI, 1/2: $1-15$.

Burnes A. (1833). On the Reputed Descendants of Alexander the Great in the Valley of the Oxus. Journal of the Asiatic Society of Bengal 2: 305-307.

Burnes A. (1838). On the Siah Posh Kaffirs with Specimens of Their Language and Costume. Journal of the Asiatic Society of Bengal 7: 325-33.

Burnes A. (2003), Cabool. Being a Personal Narrative of a Journey to, and Residence in that City, in the Years 1836,7 , and 8. National College of Arts. Lahore. Or. ed. London, 1842.

Cacopardo A.M. (1991). The Other Kalasha. A Survey of Kalashamun-Speaking People in Southern Chitral. Part I: The Eastern area. East \& West 41, 1/4: 273-310.

Cacopardo A.M. (1996). The Kalasha in Southern Chitral. Part I: The Eastern Area. In E. Bashir \& Israr-ud-Din (eds.) 1996: 247270.

Cacopardo A.M. (forthcoming). Chi ha inventato la democrazia? 
Cacopardo A.M. \& A.S. Cacopardo (1977). Circuiti di scambio economico e cerimoniale presso i Kalash (Pakistan). Uomo \& Cultura 19/22: 106-119.

Cacopardo A.M. \& A.S. Cacopardo (1989). The Kalasha (Pakistan) Winter Solstice Festival. Ethnology 28, 4: 317-329.

Cacopardo A.M. \& A.S. Cacopardo (1992). The Other Kalasha. A Survey of Kalashamun-Speaking People in Southern Chitral. Part III: Jinjeret Kuh and the Problem of Kalasha origins. East \& West 42, 2/4: 333-375.

Cacopardo A.M. \& A.S. Cacopardo (1995). Unknown Peoples of Southern Chitral. Part I: The Dameli. East \& West 45, 1/4: 233282.

Cacopardo A.M. \& A.S. Cacopardo (1996). The Kalasha in Southern Chitral. Part III: Jinjiret Kuh and the Problem of Kalasha Origins. In E. Bashir \& Israr-ud-Din (eds.) 1996: 299-313.

Cacopardo A.M. \& A.S. Cacopardo (2001). Gates of Peristan. Istituto Italiano per l'Africa e l'Oriente. Roma.

Cacopardo A.M. \& R. Laila Schmidt (eds) (2006) My Heartrendingly Tragic Story. Novus. Oslo.

Cacopardo A.S. (1991). The other Kalasha. A Survey of KalashamunSpeaking People in Southern Chitral. Part II: The Kalasha of Urtsun. East \& West 41, 1/4: 311-350.

Cacopardo A.S. (1996). The Kalasha in Southern Chitral. Part II. The Pre-Islamic Culture of the Urtsun Valley. In E. Bashir \& Israrud-Din (eds) 1996: 271-98.

Cacopardo A.S. (2008). The Winter Solstice Festival of the Kalasha of Birir: Some Comparative Suggestions. Acta Orientalia 69: 73115.

Cacopardo A.S. (2010) Natale pagano. Feste d'inverno nello Hindu Kush. Sellerio. Palermo.

Capus G. (1889). Le Kafiristan et les Kafirs Siah-Pouches. In Quatrième Congrès International des Sciences Géographiques, Le Mans, 5-47. 
Cardini F. (1995). Il cerchio sacro dell'anno. Il Cerchio. Rimini.

Caroe O. (1958). The Pathans. London. Repr. Karachi, 1973.

Cunningham A. (1854). Ladakh. Physical, Statistical and Historical. London.

Daniélou A. (1980). Shiva e Dioniso. Ubaldini. Roma. Or. ed. Shiva et Dionysos. Paris: Arthème Fayard, 1979.

Decker, K. (1992) Languages of Chitral. Sociolinguistic Survey of Northern Pakistan. 5 voll., vol. 5. National Institute of Pakistan Studies and Summer Institute of Linguistics. Islamabad.

Dughlat Mirza Muhammad Haidar (1895). Tarikh-i-Rashidi. A history of the Moghuls of Central Asia. An English Version, Edited, with Commentary, Notes and Map by N. Elias, Translation by E. Denison Ross. London.

Dumézil G. (1929). Le problème des Céntaures. Librairie orientaliste Paul Geuthner. Paris.

Dumont L. (1979). Homo Hierarchicus. TEL Gallimard. Paris. Or. ed. 1966.

Edelberg L. \& S. Jones (1979). Nuristan. Graz.

Edelman D.I. (1983). The Dardic and Nuristani Languages. Nauka. Moscow.

Eliade M. (1968) Il mito dell'eterno ritorno. Borla. Roma. Or. ed. Gallimard. Paris 1949.

Eliade M. (1979). Storia delle credenze e delle idee religiose. Sansoni. Firenze. Or. ed. Payot. Paris 1975.

Elphinstone M. (1815). An Account of the Kingdom of Caubul, and its Dependencies in Persia, Tartary, and India. London. Repr. Graz, 1969.

Firasat S., Khaliq S., Mohyuddin A., et al. (2007). Y-chromosomal evidence for a limited Greek contribution to the Pathan population of Pakistan. European Journal of Human Genetics, 15: 121-126. Published online 18 October 2006. 
Frazer J.G. (1987). The Golden Bough. Papermac. London. Or. ed. Macmillan, London 1922.

Frembgen J. (1992). Historical Rivalry and Religious Boundaries in the Karakorum: the Case of Nager and Hunza. In C.-A. Seyschab, A. Sievers, S. Szynkiewicz (eds.), Frontiers, Boundaries, Limits. Their Notions and Experiences in East Asia. Unkel - Bad Honnef.

Fussman G. (1972). Atlas linguistique des parlers dardes et kafirs. Vol. 1: Cartes. Vol. 2: Commentaire. Paris.

Fussman G. (1976). Review of Jettmar (1975). Journal Asiatique 264, 1: 200-209.

Fussman G. (1977). Pour une problématique nouvelle des religions indiennes ancienne. Journal Asiatique 265, 1/2: 21-70.

Fussman G. (1983). Nouveau ouvrages sur les langues et civilisation de l'Hindou-Kouch (1980-82). Journal Asiatique 271, 1/2: 191-206.

Fussman G. (1988). La strada dimenticata fra l'India e la Cina. In $I$ viaggi della storia. Dedalo, 33-51. Bari. Or. ed. in L'histoire, 1982-86.

Gnoli G. (1980). Zoroaster's Time and Homeland. A Study on the Origins of Mazdeism and Related Problems. Istituto Universitario Orientale. Napoli.

Graziosi P. (1961). The Wooden Statue of Dezalik, A Kalash Divinity, Chitral, Pakistan. Man 183, 1: 49-151.

Graziosi P. (1964). Prehistoric research in Northwestern Punjab. Anthropological research in Chitral. In A. Desio (ed), Italian Expeditions to the Karakorum (K2) and Hindu Kush. Scientific Reports (V-Prehistory-Anthropology). Leiden.

Graziosi P. (2004). Pakistan 1955 - Appunti di viaggio di Paolo Graziosi. A cura di S. Ciruzzi, S. Mainardi \& M.G. Roselli. Archivio per l'antropologia e la etnologia CXXXIV: 3-100.

Graziosi P. (2007). Pakistan 1960 - Appunti di viaggio di Paolo Graziosi. A cura di S. Ciruzzi, S. Mainardi \& M.G. Roselli. Archivio per l'antropologia e la etnologia, CXXXVII: 3-133. 
Grossato A. (2008). Alessandro Magno e l'India. Storico intreccio di miti e di simboli. In Quaderni di Studi Indo-Mediterranei, I, Alessandro/Dhû l-Qarnayn in viaggio tra i due mari, C. Saccone (ed.). Edizioni dell'Orso. Alessandria.

Guillard J. (1974). Seul chez les Kalash. Carrefour des lettres. Paris.

Heegård J. (2006). Local Case Marking in Kalasha. PHD Dissertation. University of Copenhagen.

Herrlich A. (1938). Land des Lichtes. Deutsche Kundfahrt zu unbekannten Völkern im Hindukusch. München.

Holdich T.H. (1896). Origin of the Kafirs of the Hindu Kush. The Geographical Journal 6: 42-49.

Holzwarth W. (1994). Die Ismailiten in Nordpakistan. Zur Entwicklung einer Religiösen Minderheit im Kontext neuer Aussenbeziehungen. Ethnizität und Gesellschaft: Occasional Papers 21.

Holzwarth W. (1996). Chitral history, 1540-1660: Comments on Sources and Historiography. In E. Bashir \& Israr-ud-Din (eds) 1996: 117-34.

Holzwarth W. (1999). Materialien zur Geschichte des Karakorum und östliches Hindukusch 1500-1800. Wandel im vorkolonialen Gebirgsraum. Ein Projekt im Schwerpunktprogramm Kulturraum Karakorum der Deutschen Forschungsgemeinshaft. Unpublished manuscript.

Holzwarth W. (2006). Sources of Gilgit, Hunza and Nager History (1500-1800). In H. Keutzmann (ed), Karakorum in transition. Oxford University Press. Karachi.

Hutton R. (2001). Stations of the sun. Oxford University Press. New York. Or. ed. 1996.

Jeanmaire, H. (1972) Dioniso. Religione e cultura in Grecia. Einaudi. Torino. Ed. or. 1951, Payot. Paris.

Jettmar K. (1965). Fruchtbarkeitsrituale und Verdienstfeste im Umkreis der Kafiren. Mitteilungen der Anthropolgischen Gesellschaft in Wien 95: 109-18. 
Jettmar K. (1974a). Introduction. In K. Jettmar \& L. Edelberg (eds) 1974.

Jettmar K. (1974b). Iranian Influence on the Culture of the Hindukush. In K. Jettmar \& L. Edelberg (eds) 1974: 39-43.

Jettmar K. (1975). Die Religionen des Hindukush. Die Religionen der Menscheit. Vol. 4, 1. Stuttgart.

Jettmar K. (1977). Bolor: a Contribution to the Political and Ethnic Geography of North Pakistan. Zentralasiatische Studien 11: 411-448.

Jettmar K. (1982). Rockcarvings and Inscriptions in the Northern Areas of Pakistan. Institute of Folk Heritage. Islamabad.

Jettmar K. (1996). Approaches to the History of North Pakistan. In E. Bashir \& Israr-ud-Din (eds.) 1996: 77-96.

Jettmar K. \& L. Edelberg, eds (1974). Cultures of the Hindu Kush: SelectedPpapers from the Hindu Kush Cultural Conference held at Moesgård 1970. Wiesbaden.

Jones S. (1966). An Annotated Bibliography of Nuristan (Kafiristan) and the Kalash Kafirs of Chitral. Det Kongelige Danske Videnskabernes Selskab. Historisk-filosofiske Meddelelser. 41, 3. Copenhagen.

Jones S. (1969). A Bibliography of Nuristan and the Kalash Kafirs of Chitral, Part Two: Selected Documents from the Secret and Political Records, 1885-1900. Det Kongelige Danske Videnskabernes Selskab. Historisk-filosofiske Meddelelser. 43, 1. Copenhagen.

Kakar H. (1971). Afghanistan, a Study in Internal Political Developments, 1880-1896. Punjab Educational Press. Lahore.

Keay J. (1990). The Gilgit Game. Oxford University Press. Karachi. Or. ed. 1979.

Kirfel W. (1953). Siva und Dionysos. Zeitschrift für Ethnologie 78: 83-90.

Leitner G.W. (1894). Dardistan in 1866, 1886 and 1893. Woking. Repr. Karachi, 1985. 
Leitner G.W. (1895). The Future of Chitrál and Neighbouring Countries. Reprinted from the Asiatic Quarterly Review, July 1895, with the addition of an appendix, routes, etc. In B. Lasker, Human Bondage in Southeast Asia. Chapel Hill, 1950.

Lockhart S.A. \& R.G. Woodthorpe (1889). The Gilgit Mission, 188586. Eyre and Spottiswoode. London.

Lorimer D.L.R. (1929). The Supernatural in the Popular Belief of the Gilgit Region. Journal of the Royal Asiatic Society of Great Britain and Ireland: 507-536.

Lorimer D.L.R. (1935). The Burushaski Language (3 vols). Vol. 2: Texts and translations. Instituttet for Sammenlignende Kulturforskning. Serie B. 29, 2. Oslo.

Loude J.-Y. (1980). Kalash. Berger-Levrault. Paris.

Loude J.Y. \& V. Lièvre (1984). Solstice paien. Presses de la Renaissance. Paris.

Maggi W. (2001). Our Women are Free. Gender and Ethnicity in the Hindu Kush. The University of Michigan Press. Ann Arbor.

Mallory J.P. (1989). In Search of the Indo-Europeans. London \& New York: Thames and Hudson.

Mansoor A, Mazhar K, Khaliq S. et al. (2004): Investigation of the Greek ancestry of populations from northern Pakistan. Human Genetics, 114, 5: 484-490.

Maraini F. (1997). Gli ultimi pagani. Red Edizioni. Como. Or. ed. in Paropàmiso. Bari, 1963.

Masica C.F. (1991). The Indo-Aryan Languages. Cambridge University Press. Cambridge.

Masson C. (1842). Narrative of Various Journeys in Balochistan, Afghanistan, the Panjab and Kalat, During a Residence in Those Countries, to which is added an Account of the Insurrection at Kalat and a Memoir on Eastern Balochistan (4 vols). Vol. 1. London. Repr. Graz, 1975. 
McGovern P.E. (2004). L'archeologo e l'uva. Carocci. Roma. Or. ed. Ancient Wine. The Search for the Origins of Viniculture. Princeton University Press, 2003.

McKim Marriott (1968). The feast of love. In Milton Singer (ed.), Krishna, myths, rites, and attitudes. The University of Chicago Press. Chicago \& London. Or. ed. University of Hawaii, 1966.

Merkelbach R. (1991). I Misteri di Dioniso. Genova: ECIG. Or. ed. Stuttgart, 1988.

Mohan Lal (1834). Further Information Regarding the Siah Posh Tribe, or Reputed Descendants of the Macedonians. Journal of the Asiatic Society of Bengal 3: 76-79.

Morgenstierne G. (1929). Indo-Iranian Frontier Languages. 1. Parachi and Ormuri. Instituttet for Sammenlignende Kulturforskning. Ser. B. 11. Oslo.

Morgenstierne G. (1932). Report on a Linguistic Mission to NorthWestern India. Instituttet for Sammenlignende Kulturforskning. Ser. C. 1, 3. Oslo.

Morgenstierne G. (1947). The Spring Festival of the Kalash Kafirs. In India Antiqua, a volume of Oriental studies presented to J.P. Vogel: 240-248. Leyden,

Morgenstierne G. (1951). Some Kati Myths and Hymns. Acta Orientalia 21: 161-89.

Morgenstierne G. (1965). Notes on Kalasha. Norsk Tidsskrift for Sprogvidenkap 20: 183-238.

Morgenstierne G. (1973a). The Kalasha Language. Indo-Iranian Frontier Languages. Vol. 4. Oslo.

Morgenstierne G. (1973b). Genealogical Traditions among the KatiKafirs. In G. Morgenstierne, Irano-Dardica. Beiträge zur Iranistik. 5: 307-316. Ludwig Reichert. Wiesbaden.

Morgenstierne G. (1974). Languages of Nuristan and Surrounding Regions. In K. Jettmar \& L. Edelberg (eds) 1974: 1-10. 
Müller-Stellrecht I. (1980). Materialien zur Ethnographie von Dardistan (Pakistan). Aus den nachgelassene Aufzeichnungen von D.L.R. Lorimer. Teil II/III: Gilgit, Chitral und Yasin. Graz.

Murtaza G. (1982). New History of Chitral (Nai Tarikh, Chitral). Translated from the Urdu version into English by Wazir Ali Shah. Unpublished manuscript. Or. ed. 1962.

Neubauer, H.F. (1974) Die Nuristanrebe, Herkunft der Edelrebe und Ursprung des Weinbaues. Afghanistan Journal, 1, 2. 32-6.

Olmo H.P. (2000). The Origin and Domestication of the Vinifera Grape. In P.E. McGovern, S.J. Fleming and S.H. Katz (eds.) The Origins and Ancient History of Wine, 31-44. Routledge. London.

Otto W.F. (2006). Dioniso. Il melangolo. Genova. Or. ed. Dionysos. Frankfurt, 1933.

Parkes P. (1983). Alliance and Elopement: Economy, Social Order and Sexual Antagonism Among the Kalasha (Kalash Kafirs) of Chitral. PHD dissertation. Oxford University.

Parkes P. (1987). Review of Jettmar, K., The Religions of the Hindu Kush: the Religion of the Kafirs, vol.1, Warminster 1986. Man 22, 3: 581-582.

Parkes P. (1991). Temple of Imra, Temple of Mahandeu: a Kafir Sanctuary in Kalasha Cosmology. Bulletin of the School of Oriental and African Studies 54, 1: 75-103.

Polo M. (2005). Il Milione. Einaudi. Torino.

Propp V. (1978). Feste agrarie russe. Dedalo. Bari. Or. ed. Leningrad, 1963.

Raverty H.G. (1859). Notes on Kafiristan. Journal of the Asiatic Society of Bengal 28: 213-268.

Raverty H.G. (1864). On the Language of the Siah Posh Kafirs. Journal of the Asiatic Society of Bengal 33, 3: 267-278.

Raverty H.G. (1888). Notes on Afghanistan and Part of Baluchistan, Geographical, Ethnographical and Historical, Extracted from 
the Writings of Little Known Afghan and Tajik Historians. London. Repr. Lahore, 1976.

Rennell J. (1792). Memoir of a Map of Hindoostan; or the Mogul Empire. The Second Edition. With very considerable additions, and many corrections. Bulmer \& Co. London.

Robertson G.S. (1896). The Kafirs of the Hindu Kush. London. Repr. Karachi, 1974.

Rousselet M.L. (1885). Le Kafiristan et les Kafirs. Revue d'ethnographie 3: 218-226.

Schomberg R.C.F. (1935), Between the Oxus and the Indus. London. Repr. Lahore, n.d.

Schomberg R.C.F. (1938). Kafirs and Glaciers, Travels in Chitral. Hopkinson. London.

Sergent B. (1997). Genèse de l'Inde. Payot et Rivage. Paris.

Shah Wazir Ali (1974). Notes on Kalash Folklore. In K. Jettmar \& L. Edelberg (eds) 1974: 69-80.

Sidky H. (1999). Alexander the Great, the Graeco-Bactrians, and Hunza: Greek descent in Central Asia. Central Asiatic Journal 43,2 .

Siiger H. (1956). Ethnological Field Research in Chitral, Sikkim and Assam. Det Kongelige Danske Videnskabernes Selskab 35, 2: 5-35.

Siiger H. (1963). Shamanism among the Kalash Kafirs of Chitral. Folk 5: 295-303.

Siiger H. (1967). Shamanistic ecstasy and supernatural beings. A Study Based on Field-Work among the Kalash Kafirs of Chitral from the Third Danish Expedition to Central Asia 1947-54. Scripta Instituti Donneriani Aboensis 1: 69-81.

Siiger H. (1974). The Joshi of the Kalasha. Main Traits of the Spring Festival at Balanguru in 1948. In K. Jettmar \& L. Edelberg (eds) 1974: 87-92.

Snoy P. (1959). Last Pagans of the Hindu Kush. Natural History 68, 9: 520-529. 
Snoy P. (1960). Kalasch - Nordwestpakistan (Chitral). Almauftrieb mit Opfern. Encyclopaedia Cinematografica 3, 12. Gottingen.

Snoy P. (1965). Das Buch der Kalasch. Ruperto-Carola. Mitteilungen der Vereinigung der Freunde der Studentenschaft der Universität Heidelberg 38: 158-162.

Snoy P. (1974). Dizila Wat! In Jettmar \& Edelberg (eds) 1974: 84-86.

Snoy P. (2008) The Rites of the Winter Solstice among the Kalash of Bumburet. Journal of Asian Civilizations, XXXI, 1/2: 36-64. Islamabad.

Spineto N. (2005). Dioniso a teatro: il contesto festivo del dramma greco. L'Erma di Bretschneider. Roma.

Stein M.A. (1928). Innermost Asia. Detailed Report of Explorations in Central Asia, Kan-su and Eastern Iran (4 vols). Vol. 1. Oxford.

Stein M.A. (1996). On Alexander's Track to the Indus. Personal narrative of Explorations of the North-West frontier of India. Asian Educational Services. New Delhi. Or. ed. London, 1929.

Strand R.F. (2001). The Tongues of Peristan. In Cacopardo \& Cacopardo 2001: 251-259.

Strand R.F. (1997-2008). Nuristan. Hidden Land of the Hindu-Kush. http://users.sedona.net/ strand/index.html.

Strand R.F. (1998). Peoples and Languages of Nuristan. An Overview of the Nuristani Languages. In R.F. Strand 1997-2008.

Stutley M. \& J. Stutley (1980). Dizionario dell'Induismo. Ubaldini. Roma. Or. ed. A Dictionary of Hinduism. Routledge \& Kegan Paul, London 1977.

Tanner H.C. (1879). Letter from Major H.C.B. Tanner on the Kafir language. Proceedings of the Asiatic Society of Bengal 3: 75-7.

Tanner H.C. (1891). Notes on the Inhabitants of the Himalayas. Scottish Geographical Magazine 7: 581-585.

Trail G.H. (1996). Tsyam Revisited: a Study of Kalasha Origins. In E. Bashir \& Israr-ud-Din (eds) 1996: 359-376. 
Trail R.L. \& G.R. Cooper (1999). Kalasha Dictionary. Summer Institute of Linguistics and National Institute of Pakistan Studies. Islamabad.

Tucci G. (1963). Oriental notes (II). An Image of a Devi Discovered in Swat and Some Connected Problems. East \& West 14, 3/4: 146-82.

Tucci G. (1977). On Swat. The Dards and Connected Problems. East \& West 27, 1/4: 9-104.

Turner R.L. (1966). A Comparative Dictionary of the Indo-Aryan Languages. Oxford University Press. London.

Van Gennep A. (1988). Manuel de folklore français contemporain. Cycle des douze jours: de Noël aux Rois.Vol. 8, 1. Picard. Paris.

Vansina J. (1976). La tradizione orale. Officina Edizioni. Roma. Or. ed. De la tradition orale. Essai de méthode historique. Musée Royal de l'Afrique Centrale, Tervuren, 1961.

Vigne G.T. (1840). Personal Narrative of a Visit to Ghuzni, Kabul and Afghanistan and of a Residence at the Court of Dost Mohamed: with Notices of Runjit Singh, Khiva, and the Russian Expedition. London.

Vigne G.T. (1842). Travels in Kashmir, Ladak, Iskardu, the Countries Adjoining the Mountain-Course of the Indus, and the Himalaya, North of the Panjab. London.

Witzel, M. (2004) The Rgvedic Religious System and its Central Asian and Hindu Kush Antecedents. In: Griffiths, A. \& J.E.M. Houben (a cura di), The Vedas, Texts, Language \& Ritual. Proceedings of the Third International Vedic Workshop, Leiden 2002. Egbert Forsten, Groningen.

Wood J. (1872). A Journey to the Sources of the River Oxus. New edition, edited by his son, with an essay on the geography of the valley of the Oxus by Colonel Henry Yule. London. 1st ed. 1841.

Wutt K. (1983) Chaumos = Vier Mal Fleisch: Notizen zum Winterlichen Festkalender der Kalash von Bumburet, Chitral. Archiv für Völkerkunde, 37: 107-148. 
Yule H. (1882). Kafiristàn. Encyclopaedia Britannica. 9th ed.

Yule H. \& H. Cordier (1921). The Book of Ser Marco Polo the Venetian Concerning the Kingdoms and Marvels of the East. Third edition, revised throughout in the light of recent discoveries by Henri Cordier (of Paris). London.

Zoller C.P. (2010) Aspects of the Early History of Romani. Acta Orientalia, 71: 243-312. 
